\title{
Symphytosociological nomenclature: new proposals
}

\author{
Jesús Izco (*)
}

\begin{abstract}
Izco, J. Symphytosociological nomenclature: new proposals. Lazaroa 35: 191-194 (2014).
A new nomenclatural formula for vegetation series is proposed that is more closely in line with the commonly-used forms of phytosociological nomenclature. The concept of facies associated to the appearance of a vegetation series is defended, and its advantages in mapping plant landscapes.
\end{abstract}

Keywords: Concept of facies, ICPN, Synassociation names, Sigmetum, Vegetation complex.

Resumen: Izco, J. Nomenclatura sinfitosociológica: nuevas propuestas. Lazaroa 35: 191-194 (2014).

Se propone una fórmula de nomenclatura para las series de vegetación, de forma análoga a la empleada en la nomenclatura fitosociológica. Por otro lado, se propone un concepto de facies de serie de vegetación con base en su fisonomía, con ventaja sobre el concepto actual, que resulta ventajoso en la definición y cartografía de los paisajes.

Palabras clave: concepto de facies, Nombre de las sinasociaciones, Sigmetum, complejos de vegetación.

\section{INTRODUCTION}

The concept of vegetation complex, understood as a grouping of communities, had its earliest manifestations in the late 1920s (BRAUN-BLANQUET \& PAVILLARD, 1928). However, the development of the conceptual and methodological aspects of the study of plant landscapes coincided with the symposium on association complexes (sigmetum) (Internationalen Vereinigung Vegetationskunde, Germany, Rintel) held in 1977. The antecedents, concepts and different interpretations and models of nomenclature linked to this type of vegetation analysis are minutely detailed in the synthesis of the history and development of the sigmatist phytosociological science by THEURILLAT (1992).

Symphytosociology is a term proposed by BÉGUIN \& HEGG (1975) and applied to different concepts of vegetation complex developed in the 1970s. Among the various initial concepts of symphytosociology, the definition that has prospered and is now the most widely accepted is the study of complexes of plant communities, understood as the set of different succession stages (pri- serial or subserial) relating to the same potential natural vegetation (PNV) (RIVAS-MARTínEZ, 1976; Rivas-MarTínez \& al., 2007; GÉHU \& RivasMARTínEZ , 1981; GÉHU, 1977, 1979, 1987, 2006).

From the start, a hierarchical system was conceived consisting of symphytosociological ranks and nomenclatural procedures, with suffixes for the different ranks. Symphytosociological nomenclature is expressly excluded from the International Code of Phytosociological Nomenclature (ICPN, Principle I) (WEBER \& al. 2000); it is however useful to apply a nomenclature that is consistent with the bases and procedures of phytosociological nomenclature, as proposed here.

\section{CURRENT MODEL OF SYMPHYTOSOCIO- LOGICAL NOMENCLATURE}

The current models of nomenclature were developed coinciding with first steps to establish the concepts of the study of plant landscape through its plant communities (THEURILlAT, 1992). The current naming pattern of vegetation series, follo-

* Department of Botany. University of Santiago de Compostela. E-15782 Santiago de Compostela. Spain. Email: jesus.izco@usc.es 
wed by numerous phytosociologists, is based on the proposed by TÜXEN (1978), even if the Tüxen's concept is not related with a dynamic successional processes. While the idea more generally accepted today links the vegetation complex with dynamic processes of succession. The formula consists of substituting the suffix of the rank of the syntaxon, plus the incorporation of a connecting vowel -with an indication of the species epithet or not-, followed at the end by the suffix "sigm-" plus the suffix for the symphytosociological rank. On occasions the term sigmetum was replaced by an upper-case letter $\mathrm{S}$.

$\begin{array}{ll}\text { Rank } & \text { Suffix } \\ \text { Synsubassociation } & \text { sigmetosum } \\ \text { Synassociation } & \text { sigmetum }\end{array}$

Examples:

Bupleuro rigidi-Querceto rotundifoliae sigmetum (Rivas-Martínez, 1987).

Chamaeropo humilis-Rhamnetum lycioidis S. (Peinado \& al., 1982).

\section{NEW PROPOSAL FOR SYMPHYTOSOCIO- LOGICAL NOMENCLATURE}

In the field of vegetation complexes, the addition of the indicative of rank at the end of the syntaxon name represents a break with the analogous model for building phytosociological names regulated by the ICPN, Arts. 10-14 (WEBER \& al., 2000). It is evident that, while parallel with phytosociological nomenclature, the procedure for symphytosociological nomenclature should be different. The aim is not to build a complex nomenclature with a formal code; however there are certain key criteria that cannot be overlooked. In addition, an analogous nomenclature at both levels reinforces the epistemological and procedural relationships between them.

The new proposal takes as an analogous model the indications of the ICPN, Art. 10 (WEBER \& al., 2000): "When a syntaxon is named after two plant taxa then, if they belong to different genera, the termination indicating the rank is appended to the stem of the second generic name only; a con- necting vowel is appended to the stem of the first generic name. When epithets of the name-giving taxa occur, they must be in the genitive, if they are declinable. When both plant taxa belong to the same genus then the generic name is used only once in the syntaxon name with the rank indicating termination; the epithets are connected by means of the connecting vowel which is appended to the stem of the first epithet".

According to the this procedure, the names of the sigmeta should be formed as follows: when the name of a vegetation complex is formed by the name of an association based on two taxa, if they belong to different genera, the indication of rank will be appended to the stem of the second generic name after a connecting vowel.

In the case of names based on two plants belonging to the same genus, the suffix indicating rank is appended to the stem of the genus after a connecting vowel; this is followed by both specific epithets, the stem of the first followed by a connecting vowel, linked to the second epithet with a hyphen. If the name of the vegetation complex is based on an association formed by a single plant, the indication of rank is appended to the root of the generic name, after a connecting vowel, while the epithet remains unchanged.

The names of subsigmeta should be formed by the name of the corresponding sigmetum, followed by the stem of the generic name of the plant that designates the subassociation, in lowercase, plus the suffix "subsigmetum" after the connecting vowel, followed by the epithet of the species designating the subassociation, in the genitive.

The connecting vowel in most cases is an ' $\mathrm{o}$ '; the connecting vowel is an ' $\mathrm{i}$ ' in third declination Latin words. In all cases, where there are specific epithets, these must be declined in the genitive, if they are declinable. For the declination of the genus names, see appendix I of the ICPN (WEBER \& al., 2000).

Examples of names based on two species from different genera:

Rusco aculeati-Quercosigmetum roboris, Lysimachio nemorum-Fagosigmetum sylvaticae, Pulmonario affinis-Abietisigmetum albae, Telino patentis-Pinosigmetum salzmannii. 
Examples of names based on two species from the same genus:

Juniperosigmetum sabino-thuriferae, Pinosigmetum uncinato-pyrenaicae.

Examples of names based on a single species:

Quercosigmetum rotudifoliae, Ziziphosigmetum loti, Juniperosigmetum turbinatae.

Example of a name of a synsubassociation:

Rusco aculeati-Quercosigmetum roboris quercosigmetosum suberis.

The nomenclatural model for synassociations (sigmeta) -that is, the base rank of symphytosociological nomenclature- is theoricaly applicable to any of the other symphytosociological ranks, with the suffixes corresponding to each rank.

\section{LANDSCAPE EXPRESSION OF SYNASSO- CIATIONS: TESSELAR FACIES}

For GÉHU \& Rivas-Martínez (1981), sigmetum or vegetation series is defined as "l'expression spatial quantifiée de tous les groupements végétaux d'une méme sèrie, a l'interieur d'une unique tessela". The emphasis on the generalist idea of the concept was later reiterated; for RIVASMARTínEZ \& al. (2007: 134) a vegetation series includes "all the set of plant communities or stages that can be found in similar tesselar spaces as a result of the succession process", whereas GÉHU (2006) defines it as the "ensemble de groupements végétaux allant vers un climax pour évolution progressive, ou s'en eloignant par évolution régressive".

However, it is almost impossible for a given area (tessela) to contain all the associations of a serial complex, as noted by JULVE (1986). The concept of vegetation complex is plural and comprises the sum of plant communities in different tesselae, each one with its own composition depending on past and present environmental factors in each case, and in a given time. The possibility of a tessela including all the substitution stages is limited to vegetation types associated with extreme biotopes, where there is no option for the existence of serial stages, or where these are restricted to one or two. This is the case of the PNV in high mountains, or first coloniser stage vegeta- tion types on dunes, marshes or lithosols, for example.

Each tessela in a plant landscape, at a given time, contains a particular composition of plant communities corresponding to a fraction of one or several successional lines in the serial complex, all of them belonging to the same PNV. From this perspective, each tessela has its own appearance, associated with the plant communities it contains, and determined in turn by the biotic and abiotic factors affecting it at a particular time. This aspect of the tesselae or tesselar facies partially corresponds to what THEURILLAT (1972) calls 'complexe tesselaire local de végétation'.

The terms facies or faciation have been previously used in symphytosociology "as the lower range of the series", without sufficient entity to constitute a series in itself, for example, in the case of series linked to subassociations of the PNV (Rivas-Martínez, 1987; GÉHU, 2006, RivasMARTíneZ \& al., 2007) that have been identified as subseries or subsigmeta. The facies, understood as the inherent appearance of each tessela at a given time, have nothing to do with the facies identified with the subseries.

The tesselar facies reveal much about the impact of anthropic or natural factors that have generated this specific, partial expression of the vegetation complex, and point to possible actions to manage its conservation or transformation. Furthermore, these tesselar facies can be easily identified and mapped as an expression of actual landscapes. They also serve as a suitable framework for conducting the synrelevés which, when grouped together, allow the reconstruction of the set of vegetation series and the identification of the most mature stage (PNV).

Identifying the tesselar facies is useful for correctly describing plant landscapes and their possible genesis or associated environmental conditions. However it is not advisable to include the tesselar facies in a regulated nomenclatural system governed by strict rules. Among other drawbacks, this would further complicate the nomenclature and probably lead to a fragmentation that would be impossible to manage. Nor would it provide significant advantages, but it could lead to an overregulation. It is more advisable to name each 
facies according to its nature, the environment in which it occurs, or its underlying causes.

The proposed regulation enables the denomination of the synassociation or synsubassociation -as the case may be-, by means of a formal system to define membership of a series and the denomination of the facies by means of an adjective or a combination of adjectives expressing the nature, structure, or determining factors in a particular plant landscape. Thus facies can be shrubby, frutescent, herbaceous, crop field, pastoral, horticultural, grazed, forested, sabulicolous, pyrophilous, silicicolous, urban, rocky, xeric, ombrophilous, etc. These examples should be written in the vernacular language and not in italics.

Example:

Rusco aculeati-Quercosigmetum roboris frutescent facies.

Bupleuro rigidi- Quercosigmetum rotundifoliae nitrophilous, crop field facies.

\section{REFERENCES}

Béguin, C. \& Hegg, O. - 1975 - Quelques associations d'associations (sigmassociations) sur les anticlinaux jurassiens recouverts d'une végétation naturel potentielle (essai d'analyse scientifique du paysage) - Doc. Phytosoc. 9: 9-18.

Géhu, J.-M. \& Rivas-Martínez, S. - 1981 - Notions fondamentales de Phytosociologie - Ber. Symp. Int. Ver. Veg. 1980: 5-33.

Géhu, J.-M. -1977 - Le concept de sigmassociation et son application à l'étude du paysage végétale des falaises atlantiques françaises - Vegetatio, 34: 117-125.

Géhu, J.-M. - 1979 - Pour une approche nouvelle des paysages végétaux: la Symphytosociologie - Bull. Soc. Bot. France 126: 213-223.

Géhu, J.-M. - 1987- Des complexes de gropupements végétaux à la Phytosociologie paysagère contemporaineInfo. Bot. Italiano, 18: 53-83.

Géhu, J.-M. -2006- Dictionaire de sociologie et synécologie végétales - J. Cramer, Berlin. 899 pp.

Julve, P. -1986 - Problèmes conceptuels dans la définition des unités de perception du paysage végétale en repport avec la gèomorphologie - Colloques Phytosoc. 14: 55-79.

Peinado, M. Alcaraz, F. \& Martínez-Parras, J.M. - 1992Vegetation of Southeastern Spain. Flora et Vegetatio Mundi, IX - J. Cramer, Berlin. 487 pp.
Rivas-Martínez, S. - 1976- Sinfitosociología, una nueva metodología para el estudio del paisaje vegetal V - An. Inst. Bot. Cavanilles 33: 179-188.

Rivas-Martínez, S. -1987- Memoria del mapa de series de vegetación de España - ICONA, Sér. Téc., Madrid. 208 pp.

Rivas-Martínez, S.; Asensi, A.; Díez-Garretas, B.; Molero, J.; Valle, F.; Cano, E. \& al. -2007- Mapa de series, geoseries y geopermaseries de vegetación de España Itinera Geobot. 17: 5-436.

Theurillat, J.-P. - 1992- Étude et cartographie du paysage végétal (Symphytocoenologie) dans la région d'Aletsche (Valais, Suise). Dévelopement historique et conceptuel de la symphytocoenologie, niveaux de perception, méthodologie, applications. Matériaux pour le levé géobotanique de la Suisse Comm. Géobot. Acad. Suisse Sci. Nat., Lausanne. $384 \mathrm{pp}$.

Tüxen, R. - 1978 - Bemerkungen zu historischen, begriffichen und methodischen Grundlagen der Synsoziologie - Ber. Symp. Int. Ver. Veg. 1977: 3-11.

Weber, H.E.; Moravec, J. \& Theurillat, J.-P. -2000 - International Code of Phytosociological Nomenclature. 3rd edition - J. Veg. Sci. 11: 739-768. 